\title{
Switzerland's refusal to join the EEA and the EC
}

\author{
René SCHWOK
}

\section{CONTENTS}

1 MOTIVES OF THE EEA'S REJECTION

1. 1 The Ethno-Cleavage

1. 2 The Question of Identity

1. 3 Erosion of Swiss Identity in the EC

1. 3. 1 Direct Democracy

1. 3. 2 Federalism

1. 3. 3 Neutrality

1. 3. 4 Immigration

1. 3. 5 Agriculture

1. 4 Moderation of the EC dangers

1. 4. 1 Direct democracy

1. 4. 2 Federalism

1. 4. 3 Neutrality

1. 4. 4 Immigration

1. 4. 5 Agriculture

2 IMPLICATIONS OF THE EEA'S REJECTION

2. 1 Political Marginalization

2. 2 Political Satellization

2. 3 Economic Marginalization

II

3 WHICH OPTIONS ?

3. 1 An Hyper-Liberal Course

3. 2 A Few Bilateral Agreements 
3. 3 Many Bilateral Agreements

3. 4 An EEA light

3. 5 EEA

3. 6 EC Membership with Opting-Outs

3. 7 Full Membership in the European Union

\section{SWITZERLAND'S REFUSAL TO JOIN THE EEA AND THE EC}

This paper explains first what are the deep motives of Switzerland's refusal to join the European Economic Area. It first points out of the ethno-cleavage, i. e. the differences between French-speaking-and-Germanspeaking-Swiss. It argues that this rift comes a special relationship between a majority and a minority. The "Germanophones" control political and economic power in Switzerland. Adhesion to the EC provokes fears for some of losing their domination over the country since European integration implies the delegation of certain competences to Brussels.

"Francophones", on the other hand, are a minority in Switzerland (less than $20 \%$ ). They have a stronger tendency to doubt their independence since they often have the feeling of not being in control of the destiny of Switzerland. In consequence, they have a more relative vision of the virtues of sovereignty and direct democracy. Suffering the indifference of many Swiss-Germans, they hope, sometimes in a mythical manner, to gain more autonomy by playing the Brussels card against Berne. In fact, they believe that European integration will diminish the weight of the central state (Berne). For many "Francophones", Europe rhymes with openness, communication to other cultures and respect of minorities. Thus the "Francophone" Swiss who support the Community have developed two myths : the Swiss myth of liberty, autonomy and federalism with the European myth of liberty, autonomy and federalism.

Moreover, Swiss-Germans try to differentiate themselves from Germany. They fear that certain real (physical, technical and fiscal) and symbolic bor- 
ders be abolished. The "Francophones", on the contrary, have more sympathy for France; which however is not comparable to a will of identification. One explanation of this is the fact that Swiss-German collective memory is marked by the remembrance of the process of German unification and the two world wars, in particular the second one. "Francophones", for their part, have not been threatened by France since the beginning of the 19th century.

Finally, there is a dialectic link between the growth of the two affirmations. The more the Swiss-German try to differentiate themselves from the external world, and in particular from the Germans, the more they express themselves in the audio-visual media, in the administration, and sometimes even at university in a dialect that most of the "Francophones" do not understand.

More generally, the question of identity is at the heart of the refusal of a majority of Swiss to integrate the European Economic Area. The EC is often characterized as hegemonic, centralist and bureaucratic, the opposite of the so-called "Swiss values" of neutrality, federalism and democracy. Moreover, integration in the EC asks of Switzerland to accept the free establishment of all Western Europeans. Therefore, many Swiss fear a "foreign invasion". Membership in the EC Common Agricultural Policy (not in the EEA) could also lead to a collapse of Swiss agriculture, especially in Alpine areas. This study analyzes the validity of the arguments against EC integration and concludes that those "Swiss values" (direct democracy, federalism, neutrality, restrictive immigration and agriculture) will be better defended by joining the EC system rather than by staying outside the Community. This analysis is based on empirical evidence that Switzerland's rejection of the European Economic Area means a mixture of political marginalization, political satellization and economic marginalization.

Finally, this paper discusses the options left to Switzerland. It analysis rapidly seven possibilities: an hyper-liberal course, a few biateral agreements, many bilateral agreements, an EEA light, an EEA membership, an EC membership with opting-outs, and a full membership in the European Union 
foreseen by the Maastricht treaty. It concludes that an EC membership with opting-outs is the only possibility due to the Swiss deep reluctance towards the EC system and that it will anyway take time for being achived.

\section{Introduction}

Switzerland refused to join the European Community (EC) because the aims of the EC were seen as incompatible with the principles laid down in Switzerland's constitution such as neutrality, direct democracy, and federalism. Moreover, the Swiss government did not want to jeopardize Swiss agriculture by entering the Common Agricultural Policy (CAP). In the 1950s, the Swiss authorities also focused on the disadvantages of the high EC common customs tariffs which would make Switzerland less competitive. Therefore, Switzerland preferred to join the European Free Trade Association in 1960 which gave her the possibility to keep its own lower tariff towards non-European countries.

When the UK, Denmark and Ireland joined the EC in 1973, Switzerland, as well as the other EFTA countries, signed free-trade agreements with the $\mathrm{EC}$ on the removal of tariffs and quotas on industrial goods, followed by more than a hundred bilateral agreements. In the mid-1980s, when the EC became more serious about the prospect of a genuine Common market, Switzerland joined the other EFTA countries in promoting a "dynamic European Economic Space" for mainly economic motives, Berne did not want to stay outside the EC-1992 Internal market.

Until January 1989, the Swiss Confederation promoted a bilateral and local approach. In other words, Berne did not want to speak with one voice with the other EFTA countries and deal with all aspects of the EC Internal market (i. e. free movement of labour). But Jacques Delors and the Commission imposed on the EFTA countries to be one pillar of an homogeneous European Economic Area (EEA) based only on EC rules ("acquis communautaire). Therefore, Switzerland had to accept to deal multilaterally with the EC and 
to give up all claims of permanent exceptions on free movement of labour, acquisition of land by foreigners etc. Moreover, Berne did not get a good system of arbitration in case of disputes in which both sides are equally represented. Finally, Switzerland was not satisfied to be forced to accept de facto future EC directives which are relevant to keep an homogeneous European Economic Area.

Therefore, Berne decided to apply for full EC membership (June 1992). In order to justify its new position, the Swiss government stressed first the above mentioned liabilities of the EEA treaty. He also pointed out three new elements : (1) the end of the Cold War makes it necessary to reinterpret the Swiss conservative interpretation of its neutrality in order to make it compatiable with a European Union membership; (2) the Maastricht Treaty (signed in February 1992) means that the European Community will develop further and that it will be even more difficult to join it later; (3) Switzerland should not let the other main EFTA countries join the EC and get a better deal than the one that Switzerland would get later.

On December 6th 1992, the Swiss voters nevertheless decided not to join the European Economic Area. Switzerland is now the only western European country remaining outside the European Community system, it is a self-appointed pariah. Therefore, one should answer at least three questions : (1) what are the deep motives of the Swiss rejection of EEA membership and EC integration? (2) what are the consequences of this solitary course? and (3) what are the different options left to Switzerland?

\section{MOTIVES OF THE EEA'S REJECTION}

\section{1 The Ethno-Cleavage}

Why did $50.3 \%$ of the Swiss taking part in the referendum turn against the EEA, and especially 18 of the 26 cantons and half cantons? Why did the Swiss-Germans reject this treaty by $56 \%$ and the Swiss-Italians by 61.5 \%) despite the strong endorsement of the EEA treaty by the two chambers of 
the parliament, almost all major political parties, the Confederation of industrialists and the trade unions? But why also were all the French-speaking cantons in favor of the EEA, by nearly $72 \%$, more than in most referenda about the European Community? Why in bilingual cantons such as Berne, Fribourg and Wallis did the Swiss-Germans reject the treaty while the neighbouring French-speaking Swiss support it?

First, it is important to point out that at least since 1986, all opinion polls showed this overall sympathy of the French-speaking Swiss ("Romands") for the Commonity idea. This means that the ethno-cleavage is independent of the details of the EEA agreement (signed in Porton in May 1992). So in our assumption, the differences between the two main Swiss communities have to do with rationalities which are mainly independent of the real nature of the EEA.

Many German-speaking Swiss dislike the Community for a number of reasons. First they master the political power. By joining the EC, some of them fear to lose their control on the country. For most of them, notions such as independence, sovereignty, neutrality, direct democracy and federalism seem to keep some meaning. On the contrary, the French-speaking Swiss are a minority in Switzerland (around $22 \%$ ). They tend to doubt that they are independent as they do not master their fate in Switzerland. They have a more relative view of the virtues of sovereignty and direct democracy although they cherish their cantonal autonomy. Suffering from the relative indifference of the Swiss-Germans, they hope, sometimes mythically, to get more autonomy by playing Brussels against Berne. By supporting by nearly $75 \%$ the EEA agreement, the French-speaking Swiss express as much irrationality as do the Swiss Germans who reject it. Irrationality means here that both communities expressed political behaviors largely independent of the real nature of the EEA.

Second, German-speaking Swiss try to differentiate themselves from Germany, to avoid becoming another "Land" and to lose their own identity. They fear an integration a Community dominated politically by Germany. 
The French-speaking Swiss, by contrast, have no fear of the Gallic neighbour.

Third, there is a dialectical link between the rise of the two main ethno-nationalisms. The more the Swiss-Germans try to differentiate from the outside word, and especially from the Germans, the more they speak a non-written dialect at the levels of the mass-media, the university and even the administration. At the same time, the German-speaking Swiss practice less and less the French language as the Anglo-Saxon and German worlds are getting more attractive than France from a cultural point of view. This makes communication difficult with the French-speaking Swiss as most of them ignore this non-written dialect. Therefore, most of the "Romans" cannot communicate with the Swiss-Germans as they do not understand them.

\section{2 The Question of Identity}

Identity is at the heart of the refusal of a majority of Swiss to integrate the European Economic Area. The EC is often characterised as hegemonic, centralist and bureaucratic, the opposite of the so-called "Swiss values" of neutrality, federalism and democracy. Moreover, integration in the EC asks of Switzerland to accept the free establishment of all Western Europeans. Therefore, many Swiss fear a "foreign invasion". Membership in the EC Common Agricultural Policy (not in the EEA) could also lead to collapse of Swiss agriculture, especially in Alpine areas. Everyone knows that territory is linked to all nationalisms. Switzerland's nationalism is closely related to the mountains and its landscape. Two Swiss symbols should be pointed out : first, the main Swiss place of memory is the Grutli meadow, not a tower, a castle, a cathedral or an arch of triumph. Second, during the Second World War, the army planned to defend only the mountainous part of the country against a German invasion (concept of "national réduit"), not the densely populated urban areas.

To sum-up, the Swiss have developed a myth that they can reconcile freedom and nature. Many Swiss Germans still believe that they can maintain 
their freedom from the outside world, their independence, as well as their smallness their local autonomy, their ideological purity and their close links with the earth. To be sure, in Swiss-German cities, the myth is less strong as more people can empirically observe that reality is not dictated by notions such as federalism, direct democracy and neutrality. Awareness of the internationalisation of politics and economy is much more widespread. And more people realize that stress, over-population do not fit totally the Swiss myths.

In the French-speaking part of Switzerland, the European myth is now stronger than the Swiss myth. The "Romands" also cherish notions such as direct democracy, federalism, neutrality. And they can be xenophobic and hostile towards foreigners. In other words, the French-speaking like Switzerland and still share most of its myths. They do not have the feeling that they have been forced to join this country or that they lost their prerogatives as some French-speaking Canadians and Belgians believe. But the "Romands" suffer to be a minority in Switzerland. Therefore, the EEA, as an incarnation of the European myth, is seen as a way to get out of the "ghetto". For most "Romands", "Europe" means openness, communications with other cultures, respect of minorities. Paradoxically, French-speaking supporters of the Community have cultivated two myths : the Swiss myth of freedom, autonomy, federalism with the "European" myth of freedom, autonomy and federalism. In a sense, the French-speaking "Yes" vote is a conservative revolution.

\section{3 Erosion of Swiss Identity in the EC}

\section{3. 1 Direct Democracy}

For the anti-EEA camp, European integration will lead to damage some Swiss specificities. Thus, through the European Economic Area (EEA), direct democracy will be limited as, de facto, there will not be any possibility to adopt new legislation which does not fit EC directives. Direct democracy means two peculiar features of the Swiss political system: the "referendum" 
and the "initiative". Any bill approved by the Federal Assembly must be submitted to referendum. The bill comes into force only if no petition is made against it within 90 days. If a petition is submitted bearing the signature of no less than 50,000 citizens, a referendum is held and the final decision as to whether it shall become law rests with the people. Citizens have another means by which they can actively take part in the affairs of the country, namely by the "initiative". By this means, the people, given the support of 100,000 signatures, can demand that the Federal Constitution be amended or partially revised. Should the Federal Constitution be amended, not only is the consent of the majority of the people required in every case, but a majority is settled by first determining the majority of votes, and the proportion of votes for and against the motion in each separate canton. If there is a majority of votes as well as majority of cantons in favour of the motion, the constitution is then changed.

In case of Switzerland's application to a supranational organization like the EC or even for EEA membership, the Constitution demands a vote which requires also the double majority of the cantons and the population. Therefore, both the Federal Council and the Parliament always try to anticipate possible opposition and are led to consult the vested organizations and political parties at a very early stage of the decision-making process in order to get the largest possible approval. Here one finds two well-known features of the Swiss political system : consensualism and consociationalism.

But the EEA agreement forces the Swiss citizens to give a part of their prerogatives. Worse, it leads to an automatic diminution of those rights in the future. As a matter of fact, article 102, point 5 of the Treaty on the European Economic Area implies that if the Swiss population refused any new EC directive relevant to the EEA, the EC could almost automatically suspend the part of the Treaty which is linked to the Swiss opposition. For example, if the EC decides in a few years to ban banking secrecy and the Swiss citizens reject this new directive, the EC could suspend its agreements on banking with Switzerland. And there will not be any EEA Court of Jus- 
tice or even a balanced Court of Arbitration to assess the legitimacy $\underset{19}{\text { ) }}$ the EC decision as such courts have been refused by the EC Court of Justice.

In those conditions, it is doubtful that Switzerland, or any EFTA country linked to the EC through the EEA agreement, could avoid adopting the future EC laws although those countries are non members of the EC. Therefore, practically, the use of the instruments of direct democracy will be limited and this would be especially true in case of Switzerland's membership in the $\mathrm{EC}$.

Many German-speaking Swiss do not want to erode the system of direct democracy as they see it as a deep expression of their sovereignty. In Switzerland, the population is often called "the sovereign". Moreover, in sparsely populated cantons, (most of them are in located in the Swiss-German part), direct democracy is often linked with the concept of "Landsgemeinde", a deep mythical component of the Swiss-German identity.

The French-speaking Swiss, a minority, also want to keep the instruments of direct democracy. But they are more aware of the limits left to the population to make a large use of it. It is still cherished but not idolized.

1. 3. 2 Federalism

Federalism is another important element of the Swiss identity. The Swiss define themselves by their cantonal origin. Switzerland continues to have 26 ministers for education, health, justice, police, finance, economy and agriculture, etc. Integration in the EEA would force cantons to partly harmonize their norms in areas such as education, health and public procurements. For anti-integrationists, membership of the EEA would lead to a transfer of competences from the cantons to the central state. Participation in the EEA would modify the structure of the federal state. It can diminish the power of the cantons in the Swiss system. Concretely, anti-integrationists fear that the standardization of the legislation in the EC system trigger off modifications of cantons' laws. The main problems are : recognition of non-Swiss diplomas, new procedures of admission in schools and universities.

They also add questions of controls of cars, food, water, air, noise, and so- 
Switzerland's refusal to join the EEA and the EC (SCHWOK)

cial insurance. Anti-EC elements also mention the question of the free access of EFTA and EC citizens to public positions in the cantons. It will therefore be more difficult to derogate to the federal laws influenced by the EC directives. Moreover, anti-EEA people assume that EEA membership will lead automatically to EC membership. Therefore, they criticize a future adoption of the VAT system at EC rates (around $15 \%$ for the "normal" rate against $6.2 \%$ in Switzerland) which will lead to a diminishing of the cantons' taxation. As a consequence, as the introduction of the VAT will strengthen the federal imposition at the expense of the cantons' imposition, the cantons could lose a part of their fiscal autonomy and be more dependent on the central government, even if there is a financial redistribution. Thus, for Swiss-German even if there is a financial redistribution. Thus, for Swiss-German anti-EC lobbies, in a free-border Europe, Switzerland would lose its "raison d'être" and be dissolved in the Community cocktail. According to some Swiss-Germans, the French-speaking Swiss would join France, the Italian-speaking Italy, and the German-speaking would stay alone in Switzerland.

For many German-speaking Swiss, especially in small cantons, federalism is a means to keep the identity of communities jeopardized by the modernization process coming from the central state. Moreover, the concept of double majority in some popular votes (majority of the population and of the cantons) is seen by small cantons (almost all in the German part) as a protection of their specificities. In the French-speaking part, federalism is also seen as being of value. There is however a hope that by joining the EC system, the cantons will be less dependent upon the German-speaking majority and that there will be more possibilities to deal with the French region near the Franco-Swiss border.

\section{3. 3 Neutrality}

For those opposing the EEA, Swiss neutrality is not directly challenged by an EEA membership. But as they assume that an EEA participation will lead automatically to EC membership, they fear that Switzerland's neutrality 
will be challenged by the EEA eventually (and hence is challenged indirectly).

One should remember that neutrality is not only a strategic, legal, and economic element, it is also in Switzerland an instrument of political integration in a multi-religious and multi-linguistic federal state. Neutrality is often viewed as one of the "deepest expressions of the essence of Switzerland."

The EC jeopardizes the credibility of neutrality. As a matter of fact, if most frntiers are erased between the EC and the EFTA states, how will it be possible to maintain a credible policy of neutrality? For example, if the EC decides economic sanctions against any country, Switzerland is de facto forced to follow the EC policy and to take the side of the EC against its enemy. Already without EEA membership, Switzerland is so integrated in the EC system that it has carried out the EC sanctions against Serbia and Montenegro.

With an EC membership, not only is the credibility of Switzerland's neutrality at stake but also its law of neutrality in peace time. In fact, a new member of the EC has to adopt all the modifications of the Treaty of Rome decided in the Maastricht Treaty. A new member must accept that "the Western European Union, which is an integral part of the development of the European union, elaborate and implement decisions and actions of the Union which have defense implications." Moreover, this Western European Union (WEU) has taken the commitment "to strengthen the European pillar of the Atlantic Alliance" and to "act in conformity with the positions adopted in the Atlantic Alliance." One can interpret the policy of neutrality in many ways but not the law of neutrality. Legally, a neutral state can not belong to a military alliance in peace time.

Some people also fear that an integration of the Swiss army in an alliance dominated by the Western European Union would have consequences on its domestic function. Many officers are leading politicians and businessmen. There is still a lot of co-optation between the political and economic elite which is linked to the rank in the army. Moreover, the army is one of the 
few frameworks where Swiss males meet each other. By integrating the Swiss army in a European defense, one of the most important element of Switzerland's identity could be jeopardized.

One should keep in mind that the majority of the Swiss population has a deeply emotional attitude towards neutrality. It is an unconscious instrument of differentiation towards foreigners. It is therefore not uncommon that the EC is compared to other attempts to jeopardize Swiss sovereignty. Even in the 1990s, the EC is sometimes assimilated to Stalin's Soviet Union, Austria, Napoleon's France and Hitler's Germany. In a sense, neutrality is for the Swiss-Germans what monarchy is for the Britons: a fundamental constitutive element of their identity. Most Swiss-Germans are still convinced that their history teaches then that neutrality is the best way to save their independence, internal equilibrium and prosperity.

1. 3. 4 Immigration

Politics towards foreigners constitutes another important reason for Swiss desires to remain apart from the EC. The EEA demands indeed a free establishment of persons, free circulation of capital and service, opening of public procurements, mutual recognition of diplomas and university cooperation, all principles which unsettle the traditional Swiss policy towards foreigners.

In the 1970s, series of xenophobic popular initiatives paralyzed the Federal Council on immigration and to this day, its margin of maneuvre is limited. In the 1990s, the Swiss fear that their land will be sold off to foreign investors. A drastic law (lex Furgler / Friedrich) strongly limits any sale of real estate to not-Swiss. Takeover of Swiss firms by foreigners is also very difficult and pressures by Swiss bankers to open Swiss companies to foreign capital is still resisted. Many Swiss fear losing their jobs and having to be confronted by an invasion of persons who would neglect Switzerland's identity. In the German part, immigrants from Spain, Italy and Portugal are less integrated than in the French-part for cultural reasons. Moreover, young "Romands" are very attracted culturally by the French, Italian and British 
cultures.

\section{3. 5 Agriculture}

Agriculture is also closely linked to Swiss identity. In the 1950s, one of the main motives for not joining the Community was the notion of guaranteeing an agriculture capable of supplying the country in time of war. By joining the EC, (but not by entering the EEA), Switzerland would have to adopt the Common Agricultural Policy (CAP). This would lead to an important loss of income for Swiss farmers and boost the rural exodus. For example, one quintal of wheat is sold 100 hundred Swiss francs to the Swiss farmer, but only 30 hundred francs in the European Community where the price could be lowered by the Uruguay Round negotiations to 20 francs.

If Switzerland adopted the CAP, a part of Swiss agriculture would not be competitive. Thousands of farmers would lose their jobs. Areas, especially in the mountains, would be abandoned, the cradle of Switzerland's geography and history neglected. It is therefore obvious that the Common Agricultural Policy is seen not only as a material threat but also as a symbolic one for Switzerland's identity.

\section{4 Moderation of the EC dangers}

\section{4. 1 Direct democracy}

Concerning the instruments of direct democracy, it is important to bring some nuances. First, it will still be possible to use the instruments of referendum and popular initiative for all aspects which are not related to the EC. Moreover, even those that concern the acquis communautaire could be submitted to the popular vote if there is a question of enacting Community laws into the Swiss legal order. Finally, most popular rights in the cantons and communes will not be jeopardized.

More important, a diminution of the possibilities of using the instruments of direct democracy might contribute to diminishing the paralysis of the Swiss political system. It is sometimes very difficult to take decisions as threats of referenda are a kind of permanent blackmail. In 1992, around 15 
referenda were organized at the federal level, with many more at the canton's and commune's levels. It is impossible for any citizen, (even for a processor of political science) to have a sufficient level of knowledge to assess each problem. Thanks to EC integration, some restrictions on the possibilities of referenda might make direct democracy more attractive to the population. Swiss citizens would vote less often but with better knowledge on issues which are closer to their day to day life. They could therefore rediscover the original meaning of direct democracy and vote in a larger number.

1. 4. 2 Federalism

One should also avoid exaggerations on federalism. First, studies made by the cantons themselves recognize that adaptations will be very limited and that they will not touch the sovereignty of the cantons. Second, anti-EC lobbies underestimate the functioning of the Community, the over-representation of the small states in the Commission, in the Council of Ministers and in the Parliament. They also neglect the importance of the new approach in the White Paper which is based on the principles of a minimal compatibility and mutual recognition of norms. They also seem to ignore the principle of subsidiarity which allows the Community to legislate only where it is necessary and gives the governments the right to complain to the EC Court of Justice in case of abuses of centralization. Moreover, those anti-EC lobbies do not want to recognize the fact that the Single European Act and the Maastricht Treaty authorize the member states to refuse norms which would be inferior to their concepts of safety, health, and environment.

Finally, an integration of Switzerland in the EC could help this country to reform the function of the cantons. There are some excesses which should disappear. For instance, some diplomas are not recognized in all cantons. Lawyers from Lausanne have difficulty working in Geneva (60 km away, same language). Most canton's public procurements are not open to bidders from other cantons. One can already observe that, thanks to the EC challenge, some anomalies and anachronisms have been erased. And there are signs of "rapprochement" between different cantons in order to create more 
collaboration in education, health, taxation etc. This could lead to more cooperation between the cantons and to the creation of bigger regions which could compete with other European regions.

\section{4. 3 Neutrality}

As for armed neutrality, it is also an exaggeration to predict a dissolution of the Swiss army in a European system of collective security. First, no EC, WEU, NATO, CSCE or Franco-German project wants to dismantle national armies. Moreover, the Maastricht Agreement foresees de facto a multispeed integration: a core of member states will take part in the WEU, but other members of the EC could have a status of observers if they wish so. Moreover, the EC Edinburgh Summit (December 12, 1992), authorized Denmark to opt out a priori from the political union, namely from the European Political and Security Cooperation. Switzerland could therefore be a member of the Community without entering a military union and even the security union. With other new EC members who are also neutral (Austria, Sweden, Finland), it would be easier for Switzerland to defend such an option.

For sure, it is true that Switzerland could not remain neutral if the EC was attacked by an aggressive country. But Switzerland could nevertheless maintain its neutrality in case of conflict between its neighbours (i. e. between France and Germany) or between Third World countries. It would not be the same neutrality as today but it could be more than the neutrality of Sweden and Austria. In this situation, Switzerland could appear as more neutral than the other European countries and continue to use this concept for domestic purposes of integration and identification.

1. 4. 4 Immigration

Dangers of the free establishment of EC and EFTA citizens should also be put in perspective. First, there will not be a foreign invasion when the EEA agreement will come into force. No expect on immigration expects such a phenomenon for the following reasons.

(1) there have no been important migrations in the EC although the princi- 
ple of free establishment already exists ;

(2) the European worker prefers to stay at home unemployed (with indemnities) rather than being confronted with all the psychological, sociological, cultural and linguistic problems linked to immigration;

(3) It is mostly the needs and requirements of the country of destination which create migrations.

At the same time, thanks to the principle of free establishment, Swiss citizens will stop their rush for EC nationalities as they will not be discriminated against in Western Europe. Such an evolution might lead to a limitation on the number of people with two nationalities. More important, it will be easier to integrate EC and EFTA citizens in Switzerland who already live there, i. e., around $70 \%$ of the foreign population in this country. The overall atmosphere towards citizens from Western Europe could improve in Switzerland if procedures of naturalization were accelerated. Moreover, according to the Maastricht Treaty, if Switzerland joined the EC, those foreigners could vote for local elections and even be elected. All those factors could contribute to the development of a less discriminatory identity.

1. 4. 5 Agriculture

Finally, as for agriculture one should also be realistic and keep some sense history. Before 1914, Switzerland was not protectionist. It imported its wheat from Ukraine, and its meat from Argentina. Only with the First World War, the crises of the thirties, and the second World War did Switzerland develop an agricultural economy of war. The EEA treaty could be an interesting opportunity for reforming and liberalizing Switzerland's agriculture. As a matter of fact, the EEA should lead to cheaper prices (from 30 to $35 \%$ ) on imported goods such as farm machines, food for animals, chemical fertilizers and insecticides. There are more and more derogations in the Community. For example, it is possible to get exceptions for agriculture in mountain regions, (already above $500 \mathrm{~m}$ in altitude), and to give direct payments, as is already very common in Germany and especially in Bavaria. Switzerland can safeguard its agriculture only if it specialized in products 
that its competitors cannot make and finds "niches" in world markets. Today, Swiss cheese represents only $1.5 \%$ of the whole EC consumption. Switzerland should therefore develop its specialities. There is still room for Swiss products. Thus, paradoxically, the integration of Swiss agriculture in European agriculture could strengthen Switzerland's identity.

\section{IMPLICATIONS OF THE EEA'S REJECTION}

By refusing the EEA, Switzerland chooses a way characterized by three elements : (1) a political marginalization, (2) a political satellization and (3) an economic marginalization.

\section{1 Political Marginalization}

Political marginalization means that Switzerland is out of the main elements of EFTA as it does not participate in the EEA. This country stays only in the Secretariat but not in the supranational organization with its common decision-making process, its Court of Justice and its "Commission" (European Surveillance Authority, ESA). Switzerland is therefore a second rank member of EFTA, without any real competence for the important questions of the relations with the EC in non-tariff areas. Moreover, under the EEA agreement, the EFTA countries are to contribute 2 billion ecus between 1993 and 1995 to a fund to help the poorer EC countries. This is their entry ticket into the EC internal market. Switzerland was to pay nearly $30 \%$ of this. Now the other EFTA countries have to pay the Swiss share or they will create a crisis with Spain and its EC allies. Symbolically, Switzerland has been forced to give up to Sweden the presidency of EFTA for the first semester of 1993 (similar to the EC presidency's system). Supreme humiliation, Liechtenstein will join the EEA and will be more integrated in EFTA and in EC than Switzerland.

Vis-à-vis the EC, the situation is even worse, as Switzerland cannot negotiate through EFTA, cannot conclude substantial bilateral agreements and is 
not viewed anymore as a credible candidate for EC membership.

\section{2 Political Satellization}

This means that Switzerland is copying the EC directives as well as the EFTA laws without participating in their shaping. The Swiss parliament, the Swiss bureaucracy and the big industry want to take most of the European directives on an autonomous basis. Even at the cantonal levels, most governments and bureaucracies are doing everything to impose EC rules by all means. It is a political satellization as Switzerland cannot resist the normative attraction of the Community (and the EEA) although it is neither formally nor practically in this system.

\section{3 Economic Marginalization}

By chosing the way of a solitary course, Switzerland already suffers a terrible economic cost as this country remains outside the EC internal market and the future economic union. Even without retaliatory measures and intentional discriminations from the Community and the EFTA countries, Switzerland does not profit from all the advantages of an EEA member state. Compared to its EEA competitor benefiting from the single market, a company based in Switzerland would be submitted to the following disadvantages: survival of traditional obstacles on rules of origin, maintaining border checkpoints, costs of approval, application of different national regulations, inaccessibility of public markets, penalties for the Swiss consumer, incomplete participation in technological cooperation, lack of economies of scale, and almost no effects of competition. Thus, as Switzerland refuses to play the game of European economic competition, its competitiveness diminishes. This leads to diversion of investments and trade. According to studies made by the main Swiss banks and some economists, by not joining the EEA, investments will grow only by $0.5 \%$ instead of $3.5 \%$. As a consequence, Gross National Product (GNP) will raise by less than $1 \%$ compared to $2.3 \%$ if Switzerland entered the EC internal market. Unemployment will be doubled as compared to in- 
tegrative scenario.

Are there other alternatives for Switzerland? Anti-EEA lobbies suggest concluding bilateral and sector agreements with the EC only in the areas where there is an interest for Switzerland. But the Commission has clearly rejected such an option. The Community does not want and cannot sign agreements with Switzerland only where this country has an interest. Therefore the EC demands for instance the free movement of labour in exchange of the free movement of transport. It is indeed materially impossible for the Community to negotiate "à la carte" with each EFTA country.

Some Swiss sectors propose a hyper-liberal course.. According to this lobby, Switzerland should become more liberal than the Community and develop a world vocation. This objective usually fits the "clichés" many foreigners have about Switzerland. They often imagine this country as an "off-shore" banking place. But this is simply not the reality. Switzerland has many industries, especially small and medium, plus an agriculture, and cannot sacrifice them in the name of hyper-liberalization. Moreover, even Swiss bankers want Switzerland to join the EEA and the EC. If there were finally an agreement on the Uruguay Round negotiations (the symbol of liberalization!), there would certainly be a referendum in Switzerland with a possible rejection. Therefore, only a protectionist Alleingang is a realistic option although it would be negative. It will lead to an impoverishment of Switzerland.

\section{WHICH OPTIONS ?}

For the EC and EFTA countries, EC-1992 is already an old story. None of those States imagined that it could challenge their national identity. The Twelve and most EFTA countries think beyond 1992. But for Switzerland, the problems raised by EC-1992 are far from being solved. Switzerland has the choice between at least seven different theoretical options. 


\section{1 An Hyper-Liberal Course}

Switzerland starts an hyper-liberal course and become the Hongkong of Europe. Advantages : this country will be more open to business than the EC countries and attract investments from the whole world. Moreover, the GATT's Uruguay Round agreement will allow Switzerland to avoid some EC discriminations. Difficulties: the Uruguay Round agreement was not even initialled by the end of November 1993. And it is not sure that Switzerland will ratify it as there is a strong opposition against it. Moreover, the Uruguay Round agreement is not substantial enough in order to avoid most EC discrimination on standards, certifications, test, public procurements, free movement of persons, free movement of services, and transports. Finally, there is no majority in Switzerland for an hyper-liberal policy. Trade unions, small and medium enterprises, and farmers have enough power to stop such a policy.

\section{2 A Few Bilateral Agreements}

Berne negotiates only a few bilateral agreements, for instance on technological cooperation and exchange of students. Advantages: Brussels could more easily accept this narrow approach and Swiss domestic opposition would not be strong. Difficulties : those agreements will not be enough to offset Switzerland's political and economic marginalization.

\section{3 Many Bilateral Agreements}

Switzerland signs a maximum of bilateral and local agreements. Advantages : this country will avoid important discriminations in such fields as standards, certifications and tests. Difficulties: such a solution could be insufficient, and, above all, Brussels clearly rejects such an option.

\section{4 An EEA light}

Berne negotiates a membership in an EEA light. For instance, Switzerland would obtain an individual opting out instead of the collective opting out 
foreseen in the EEA treaty. Advantages : Switzerland could then reject future EC directives without having to be confronted to its FETA partners. Difficulties : there is absolutely no clue that the Community would be ready to grant Switzerland such a preferential treatment. Moreover, the other FETA countries will certainly refuse that Switzerland get a better deal than the one they got.

\section{5 EEA}

A new referendum on EEA membership has been called. This is the idea of a so-called "Committee born on December 7th, 1992 (founded by young people the day after the EEA was first rejected). They have successfully campaigned for a second referendum on the EEA by collecting the required 100,000 signatures. Advantages: By 1994 or 1995, the Swiss will have a clearer picture of the political and economic marginalization of their country. Moreover, there is still a large consensus of the elite and of the French-speaking part in support of the EEA. Difficulties : the Swiss do not like to vote many times on an issue they have already rejected. Moreover, EEA could be dead by 1996 if most EFTA countries join the EC.

\section{6 EC Membership with Opting-Outs}

In this case, Switzerland would obtain the same hyper-privileged statute as Denmark. For instance : Switzerland could escape the Common Agricultural Policy and the defence aspects of the Common Foreign and Security Policy. Advantages: Switzerland would be a full member of the EC and therefore participate in the decision-making process (contrary to EEA membership). And, with opting-outs, some Swiss sectors (i. e. farming) could accept more easily an EC membership. Difficulties : the EC is not even ready to grant the "Danish" statute to Sweden, Norway and Finland. A fortiori, Brussels will be even more reluctant to give more than the Danish statute, for instance on agriculture. And even with a lot of exceptions, it is not sure that the Swiss population will accept any kind of EC membership. 


\section{7 Full Membership in the European Union}

Berne starts negotiations in order to join the "Maastricht's EC", i. e. full membership in the European Union, without exceptions and special treatment. Advantages: Switzerland remains fully in the European trend. A rich, democratic, federalist country contributes to the construction of Europe. Difficulties: all opinion polls show that the Swiss refuse even more an EC membership than an EEA membership.

Finally, one should remember that any Swiss membership, either in an EEA or in EC (options 4 to 7), necessitates a double majority of the population and of the cantons. In the December 1992 referendum, 14 cantons and half cantons (out of 26) rejected an EEA membership by more than a $60 \%$ majority. It means therefore that one needs an important shift of public opinion in some cantons. This will happen only when the Swiss will be concretely aware of the political and economic marginalization of their country.

1 ) Pierre du Bois, La Suisse et le défi européen, 1945-1992, Lausanne, Favre, 1989.

2 ) René Schwok, Switzerland and the European Common Market. New York, Praeger, 1991.

3 ) René Schwok, "Switzerland and the Price of the Single European Market", in Kari Möttöla \& Heikki Patomäki (ed.). Facing the Change in Europe. EFTA Countries' Integration Strategies. Helsinki, The Finnish Institute of International Affairs, 1989 : pp. 13-21.

4) Pierre du Bois, La Suisse et l'Espace économique européen, Lausanne, L'Age d'homme, 1992, pp. 23-46.

5 ) Broadly speaking, the European Economic Area is an extension of the EC-1992 Internal market to the European Free Trade Association (EFTA) countries without formal membership in the EC. Through the EEA, there will be a free movement of goods, services, capital and persons among eighteen Western European states.

In English, on the European Economic Area, see by René Schwok the following articles: "EFTA in the 90s : Revival or Collapse ?" in J. Redmond (ed), The External Relations of the European Community: The International Response to 1992, London, Macmillan, 1992, pp. 55-76.

"EC-EFTA' Relations", in Leon Hurwitz \& Christian Lequesne (eds), The State of the European Community. Policies, Institutions \& Debates in the Transition Years, Boulder / 
Essex, Lynne Rienner / Longman, 1991; pp. 329-342.

The EC / EFTA Economic Area: A Compass for Central Europe? Program on Central and Eastern Europe Working Paper, Harvard University, Series \#14, 1991; 25 p.

6) Conseil fédéral, Rapport sur la question d'une adhésion de la Suisse à la Communauté européenne, Berne, 18 May 1992, p. 13.

7) Ibid., p. 7.

8) For a more detailed analysis, see René Schwok, "Les clivages entres Romands, Alémaniques et Tessinois" sur la question européenne, essai d'interprétation", Revue d'Allemagne, Spring 1994.

9 ) All the German-speaking cantons except Basle had important majorities against the agreement.

10) “6 décembre 1992, deux Suisse face à l'Europe", Le Nouveau Quotidien, 7 December 1992.

11) For a comparison with older opinion polls, see Roland Ruffieux and Anne-Lise Thurler Muller, "L'opinion publique face à l'intégration européenne : que disent et ne disent pas sondages?" in La Suisse et son avenir européen, Lausanne, Payot, 1989, pp. 237-252.

12) The Swiss-Italians rejected the EEA treaty for different levels of motives. First, they have made their prosperity on cheap labour, on tourism, and on tax-evasion of Italian money. Joining the EEA leads to the elimination of the statutes of cross-border workers and of seasonal workers. It also abolishes the Lex Friedrich which forbids foreigners to get Swiss land. "Tessinois" fear therefore that Germans and Italians buy their fields, and too cheap. They want to keep a tourism of quality. Finally, joining the EEA would mean more administrative cooperation between the European tax bureaucracies.

Second, many Swiss Italians are afraid by the "anarchy" and the corruption of Southern Italy and by the economic, political and cultural power of Northern Italy. By contrast, the "Romands" perceive France as a place of organization and stability, and they are not confronted by a direct competition at their borders.

13) Of course, expressions such as "French-speaking" and "German-speaking" are ideal-types in the Weberian sense and aim only at conceptualising the debate. But, for sure, one can be French-speaking and fight EC integration and German-speaking and be an EC supporter (like most of the Swiss-German political and economic elite).

14) See René Schwok, "EC-1992 and the Swiss National Identity, History of European Ideas, 1992, Vol. 15, no. 1-3, pp. 241-247.

15) See the monthly bulletins of the main anti-EC lobby: Aktion für eine unabhängige und neutrale Schweiz, in particular, May 12 1990, November 1990 and June 1991.

See also, Hugo Bütler, "Der europäische Aufbruch und die helvetische Identitätskrise", Europäische Rundschau, 2/91, p. 5.

16) Antoine Maurice, "La Suisse ou la religion du petit", Trans-européennes, No. 1, Fall 1993, pp. 20-24. 
Switzerland's refusal to join the EEA and the EC (SCHWOK)

17) They refuse to imagine the option of joining France and no political leader in the 20th century tried to raise this issue. The French-speaking Swiss are also very reluctant to look for independence. They are still many differences between the Catholic and the Protestant areas of "Romandie", between the rural and the more urban agglomerations.

18) Commission of the European Communities, The EEA Agreement, Brussels, 24 October 1991.

19) Roland Krimm, "Négociations EEE : un arbitrage limité. Le compromis juridique s'avère boiteux," Journal de Genéve, 18 February 1992.

20) Sven Bradke, "Plädoyer gegen den Beitritt der Schweiz unter dem Aspekt der Demokratie", Praetor, No 3 / 4, 1988 / 1989. Alfred Meier, "Schweizerischer Alleingang in Europa: Utopie oder Option?" Neue Zürcher Zeitung, 15 October 1990.

21) During a "Landsgemeinde", people vote or elect their representatives by handing up their hands. The "Landsgemeinde" is seen by many Swiss Germans as the ultimate form of democracy. But it is also criticized for its lack of secrecy, as everyone knows how his neighbor votes.

22) In Switzerland, (as in Germany), federalism does not mean centralization but the contrary. It is therefore considered as a value to be preserved.

23) Chr. Kr. in Aktion für eine unabhängige und neutrale Schweiz, Bern, June 1991, p. 6.

See also Peter Thürkauf, "Eigeninitiative statt Europa-Euphorie! Basler Zeitung, 12 August 1991.

24) Otto Fischer, EG / EWR: Schicksalhafe Entscheidung für die Schweiz", AG Tagblatt, 15 November 1990.

25) Wolfgang von Wartburg, Gutachten zur Neutralität der Schweiz und ihrer Zukunft, Bâle, 1992, p. 9. (Not published).

26) René Schwok, "The European Community and Switzerland: Fewer Frontiers but Continuing Neutrality", in Marko Milivojevic \& Pierre Maurer (eds), Swiss Neutrality and Security, Armed Forces, National Defence and Foreign Policy, New York, 1990, pp. 217-231.

27) Intergovernmental Conference, Treaty on European Union, Brussels, 10 December 1991, article J.4, point 2.

28) Members of the Western European Union, The Role of the Western European Union and its Relations with the European Union and with the Atlantic Alliance, Brussels, 10 December 1991, Introduction, point 1.

29) Ibid., paragraph B, point 4.

30) Hugo Bütler, "Neutralität am Ende?, in Alois Riklin (ed.), Bewaffnete Neutralität heute, Frauenfeld, 1992, p. 63.

31) Willy Futterknecht, La CE, une illusion, Schaffhausen, Novalis Verlag, 1992, p. 27.

32) Heinz Hauser, Traité sur l'EEE, adhésion à la CE, course en solitaire. Conséquences pour la Suisse, Berne, 2 June 1991, p. 77-78. 
33) Olivier Jacot-Guillarmod, "Conséquences sur la démocratie suisse d'une adhésion de la Suisse à la Communauté européenne", in Oliver Jacot-Guillarmod, Dietrich Schindler. Thomas Cottier, EG-Recht und schweizerische Rechtsordnung, Bâle, 1990, pp. 41-79.

34) Raimund Germann, "Pour une Constitution fédérale "euro-compatible", Revue de droit suisse, I, 1991, p. 1.

35) Silvio Borner, Aymo Brunetti, Thomas Straubhaar, Schweiz AG. Vom Sonderfall zum Sanierungsfall? Zürich, 1990, pp. 154-155.

36) Andreas Auer, "La démocratie directe face à l'intégration européenne", in Société genevoise de groit et de législation, La Suisse face à l'Europe, Geneva, 1991, p. 396.

37) Confédération et cantons suisses. Adaptation du droit cantonal au droit de l'EEE, (Berne: Chancelerie fédérale, décembre 1991), pp. 17-45.

For a legal analysis: Olivier Jacot-Guillarmod, "Conséquences sur le fédéralisme suisse d'une adhésion de la Suisse à la Communaté européenne" in Oliver Jacot-Guillarmod. Dietrich Schindler, Thomas Cottier, EG-Recht und schweizerische Rechtssordnung, Bâle, 1990, pp. 7-38.

38) Intergovernmental Conference, Draft Treaty on European Union, op. cit,, article 3B.

39) "Political Union: Franco-German Initiative on Foreign, Security, and Defence Policy", Europe Documents, Brussels, 18 October 1991.

"An Anglo-Italian Declaration on European Security and Defence in the Context of the Intergovernmental Conference on Political Union", Europe Documents, 5 October 1991, point 12.

40) Intergovernmental Conference, Draft Treaty on European Union, op. cit., article J. 4., point 4.

"The policy of the Union (...) shall not prejudice the specific character of the security and defence policy of certain Member States (...).

41) Member States of Western European Union, Declaration issued on the occasion of the 44th European Council meeting, Maastricht, 9 et 10 December 1991 :

"State which are members of the European Union are invited to accede to WEU (...) or to become observers if they so wish".

42) "Neutralité, défense, Europe, Interview avec Kaspar Villiger" in L'Hebdo, 6 February 1992.

Kaspar Villiger is Switzerland defense minister.

43) Thomas Straubhaar, Schweizerisch Ausländerpolitik im Strukturwandel, Strukturberichterstattung, Rüsch, Verlag Rüegger, 1991, pp. 30-45.

44) There are more than one million foreigners on a population of around 7 million. This is the highest percentage in Europe after Luxembourg.

45) Intergovernmental Conference, Draft Treaty on European Union, op. cit., article 8b.

46) Regina Flury von Arx, "EEE : saisir la dernière chance", Agri-Hebdo, 12 October 1991. 
Switzerland's refusal to join the EEA and the EC (SCHWOK)

47) Federal Council, Rapport sur l'agriculture, Berne, Office fédéral des affaires agricoles, 1992, pp. 318-319.

48) For a deeper analysis of the consequences of a solitary course, see René Schwok, Suisse - Europe. Le choix historique, Geneva, Georg, 1992, pp. 59-71.

49) For more details, see René Schwok, Switzerland and the European Common Market, New York, Praeger, 1991, pp. 71-78.

50) Urs Müller, Bei einem Nein zu Europa fehlt der 13. Monatslohn, Bern, Arbeitskreis Schweiz-Europa, Juni 1992, p. 13.

51) Jean-Jacques Roth, "Sans l'Europe, la Suisse se prépare 60,000 chômeurs de plus, "Le Nouveau Quotidien, 22 April 1992.

52) Action pour une Suisse indépendant et neutre, "Conventions avec la "CE", Bulletin, February 1992, p. 7 .

53) "Positionsbezug der EG. Strassengüter- und Luftverkehr gegen freien Personenverkehr", Neue Zürcher Zeitung, 15 September 1993.

54) Peter Moser, Schweizerische Wirtschaftspolitik im internationalen Wettbewerb, ein Ordnungspolitisches Programm, Zurich, Orell Füssli, 1991.

55) "Pressekonferenz der Bankiervereinigung. Grundsätz-liches Ja der Banken zum EWR, "Neue Zürcher Zeitung, 19 September 1991.

56) The EEA agreements excludes EFTA countries from the "comitology" on banking. "Les banques suisses mises sur la touche," Journal de Genève, 2 / 3 November 1991. 